\title{
Limited and Inadequate Governance of Limited Liability Companies in Vietnam
}

\author{
Nguyen Quy Trong \\ Faculty of Economic Law, Hanoi Law University \\ E-mail: trongltm@gmail.com
}

Received: October 11, 2018 Accepted: November 12, 2018 Published: November 14, 2018

doi: 10.5296/jsss.v6i1.13912ＵRL: https://doi.org/10.5296/jsss.v6i1.13912

\begin{abstract}
Corporate governance is a topic that many scholars have paid much attention and it is still a controversial concept among researchers in describing and applying it. This article addresses some legal issues in corporate governance of limited liability companies in Vietnam. The purpose of this study is to study the limitations and inadequacies of corporate governance in limited liability companies in Vietnam towards the development of a transparent and effective corporate governance in the market economy.
\end{abstract}

Keywords: Company, Limited liability company, Corporate governance

\section{Introduction}

Governance in an enterprise exists in a system consisting of interrelated parts, sections, interconnected parts, interactions, and mutual development. In the history of formation and development of corporate governance, there are many schools, theories on corporate governance. The classic theory of corporate governance consists of some main theories: Scientific Management of Frederich Winslow Taylor (1856-1915) et al. and the theory of administrative governance of Henry Fayol (1841-1925), theory of social psychology in corporate governance (Elton Mayo (1880-1949), Hugo Munsterberg), theory of system in corporate governance, theory of Japanese corporate governance. From the above-mentioned approach, it can be seen that corporate governance is considered a system of institutions, policies, and laws aimed at orienting, operating and controlling enterprises. Corporate governance also involves the relationship between many parties. It includes not only internal corporate members such as the board of directors, directors, members' councils, employees, etc., but also includes stakeholders outside the business such as the State management agency, business partners and community, society, etc. 
Therefore, this paper focuses on the study of existing and unreasonable issues in limited liability companies in Vietnam, thus providing some recommendations and solutions for policymakers.

\section{Governance of Limited Liability Companies}

Corporate governance is a matter of concern in the legal system of nations around the world. The law of German limited liability company in 1892 was a resounding success. Then, the model of limited liability company was quickly accepted by countries around the world, such as in Australia (1906), England (1907), France (1925), etc (Burkhard et al., 2004). In 1980, the Limited Liability Company Act was amended in 1892 and several other provisions of the commercial law were introduced. In addition, Germany has enacted a number of laws relating to companies such as Commercial Law Reform Act 1998 which came into effect on January 1999, with more extensive provisions on corporate naming. On the other hand, although the limited company model is a popular company in Germany, it is mainly established in other member countries (mainly in the UK) (Patrick, 2005).

In the United States, the United States Constitution defines the boundary between federal and state law by specifying prohibiting states from passing certain types of laws (eg, issuing private money) does not allow states laws contrary to the Constitution and federal laws. In 1874, the state of Pennsylvania enacted a law establishing a limited partnership association, which is considered to be a primitive model, bearing many similarities with today's limited company model (Martin, 2003). Besides Pennsylvania, Virginia, New Jersey, Michigan, and Ohio also issued documents similar regulations on limited partnership association.

According to the law of Vietnam, limited liability companies include limited liability company with two or more members and one-member limited liability company (Law on Enterprises 2014 in Vietnam). Two or more-member limited liability companies are enterprises, in which the members may be organizations or individuals; the number of members does not exceed 50; the member is responsible for the debts and other property obligations of the enterprise within the amount of capital contributed to the enterprise. One Member Limited Liability Company is an enterprise owned by an organization or an individual. The company owner is responsible for the debts and other property obligations of the company within the charter capital of the company. Limited liability company member with legal personality from the date of issuance of business registration certificate.

At present, the common perception of corporate governance is the system of institutions, policies, and laws that govern, operate and control the company. Corporate governance of limited liability companies is closely tied with members, owners of companies. It involves relationships within the company, between members, owners with the company director, member councils. Or it is the relationship between stakeholders, between the company and the outside of the company, such as state management agencies, partners, clients, and the social community. As such, corporate governance includes internal corporate governance through internal corporate systems and corporate governance in corporate relationships with state agencies, organizations, individuals and other partners. However, the scope of this paper is mainly focused on internal corporate governance such as principles, systems of agencies, jurisdiction, responsibilities, system or level of control, etc. Corporate governance and corporate governance are two different categories. Governance is a continuous operation and 
necessary when people work together in an organization. On the other hand, management is the process of working together and through individuals, groups and other resources (equipment, capital, technology) to achieve the goals of the organization.

Therefore, we can see the legal nature of corporate governance in limited liability companies as reflected in the following key areas: (i) division of power (centralization or decentralization) in corporate governance; (ii) the subject of management; (iii) management objectives; (iv) management resources.

\section{Limited and Inadequate Governance of Limited Liability Companies in Vietnam}

Practices in Vietnam show that the application of governance in limited liability companies has achieved certain results, but still reveals many limitations. To clarify the limitations and inadequacies of corporate governance in limited liability companies, the author conducted a survey at 400 companies in Vietnam. The results of this study indicate the problem exists in the corporate governance of limited liability such as:

\section{First, Issues related to company charter and the issuance of internal company regulations}

In the 226 limited liability companies surveyed (accounted 56.5\%), the number of limited liability companies has developed and issued company charter accounted for $60.6 \%$. This result shows that the limited liability companies build charter company at a medium level compared to other types of enterprises. Accordingly, this ratio is lower than the state enterprises which have built charter company $(83.3 \%)$ and the joint stock companies $(80.7 \%)$. However, the number of limited liability companies with the charter company is higher than private enterprises.

The limited liability companies also have issued internal regulations on good governance practices at a medium level compared to other business models. In the 226 limited liability companies surveyed, the number of companies with internal regulations was $57.1 \%$. At the same time, $100 \%$ of partnerships build internal regulations, $60 \%$ for the joint-stock company, $66.7 \%$ for FDI enterprises. Thus, it can be seen that the owners of limited liability companies are not really interested in developing internal regulations. That has affected the organization, management, and operation of the limited liability companies.

\section{Second, Issues relating to corporate governance principles}

At present, there are many schools, theories, applications of corporate governance. Each theory or school has its own approach and principles of governance. However, there are general principles that can apply to all businesses and companies. In fact, these principles also apply to a company-specific model, such as the OECD principles are applied to a joint stock company. In Vietnam, the Law on Enterprises 2014 adjusted the enterprises, from public enterprises to private enterprises, from foreign-invested enterprises to domestic-invested enterprises. Unfortunately, governments and lawmakers have not built a set of rules or corporate governance principles. Although, these are general principles and essential for corporate governance in companies. Lack of governance principles, the company will be difficult to orient enhance the competitiveness of companies in the development, planning, and implementation of policies, plans, and activities of the company.

Third, issues relating to legal representatives of the company - the subject of corporate governance. 
For limited liability companies, corporate governance always includes two types of subjects: corporate governance and subject matter management. Two types of entities have differences in terms of assets (capital) and the right to organize, manage or impact, dominant. Representation is the act of individuals, legal persons (collectively referred to as representatives) on behalf of and for the benefit of other individuals or legal persons. Representatives must have the civil legal capacity and civil act capacity compatible with civil transactions established and implemented. An enterprise may have one or more legal representatives depending on the type of enterprise. In cases where an enterprise has more than one legal representative, the signatures of the representatives at law in the enterprise registration dossier shall have the same legal value. This regulation will increase the initiative to save time and costs for enterprises when carrying out procedures for enterprise registration, especially large enterprises with many representatives at law. This regulation is aimed at creating the maximum conditions for enterprises, allowing enterprises the full right to decide the number of legal representatives for themselves in the exercise of the implementation of the rights and obligations arising from the transaction of business. The representative of the enterprise is the person with the status of the plaintiff, the defendant, the person with related rights and obligations before the arbitration, the court and other rights and obligations as prescribed by law. In the aspect of ensuring business freedom, this is a breakthrough rule in giving the business the full power to decide the number of legal representatives. It facilitates businesses to integrate faster, taking advantage of all business opportunities through legal representation.

However, in Vietnam, in accordance with the law, a limited liability company with two or more members, the Members' Council shall elect one member to act as the chairman. The chairman of the Members' Council may concurrently be the director or general director of the company. The chairman of the Members' Council and the director (General director) are entitled to various rights and obligations relating to the effective operation of the company. The actions of these managers will greatly affect the interests of the company as well as all other members of the company. In cases where the legal representative of the company is the chairman of the members' council (concurrently the director of the company), the issuance of wrong decisions, law violations or breaches of the company's charter. It would be damaging to the company and the members are great, for example in the signing and implementation of large transaction risk arising out of self-interest. Under the German company law, for a single-member limited liability company, the owner is the highest decision maker of the company. All decisions of the owner after being made must be made in writing signed by the owner. As stipulated in Article 6 of the Law on Limited Liability Companies, Limited Liability Companies may have one or more Directors. For limited companies with more than two thousand employees, in accordance with Article 33 of the Law on limited liability companies, the company must have at least two directors (Klaus J. Müller, 2009). Director Company Limited is an individual required to have full legal capacity who may be German citizens or foreigners. Persons who are or have been examined for penal liability shall not be permitted to act as directors of limited liability companies for a period of five years from the date of the court's judgment. Individuals who are disqualified by a court or competent state administrative body may not be the director of a limited liability company operating in the 
same profession. Directors are responsible for coordinating the day-to-day operations of the company and are the legal representative of the limited liability company in transactions with third parties and in litigation relations.

The division of powers and duties can help directors not be held jointly liable for the consequences of wrongdoing by another director but they are still responsible for failing to fulfill their obligation to monitor with his colleagues. In some cases, the legal representative authority of the directors may be restricted in accordance with the provisions of the company charter or the decision of the board of supervisors of the limited liability company (Karel Van Hulle and Harald Gesel, 2006).

\section{Fourth, transparency in corporate governance}

The transparency of information in corporate governance is essential to protect the interests of the company and its members. However, it should be emphasized that transparency of information is considered at different angles. The transparency of information in corporate governance may contain the potential risk of abuse of the requirement to provide information for profit or harm the business secrets of the companies, which are detrimental to company and member. The fact that valuable information or important information is only available to high-level personnel in the company such as the Chairman of the Membership Council, the Director of the company and other members in the company may be difficult to reach. Therefore, when senior executives make decisions that are primarily based on their subjective intentions. In addition, the transparency of information in corporate governance is correct, but it should be noted that it may lead to misuse of the right to information from other members or employees. So, the receipt, processing or supply of corporate governance information such as business development strategy decisions, transactional or personal information should be carefully implemented. Members, employees of the company can take advantage of the sale of information (insider trading), which results in damage to the public or the company by taking over from such acts. Identification, analysis, and processing of information are carried out according to the process. Analytical tools such as brainstorming, interviewing, root cause analysis, checklist, SWOT analysis can be used along with other tools used in the strategic planning process. However, the fact that information transparency in many limited liability companies in Vietnam does not meet the requirements of the subjects, the corporate governance.

\section{Fifth, the level of control of the self-interested actions of the company manager.}

Normally, many companies when established and put the specified information into the national portal. However, there are changes in personnel, management or capital, the company will notify the state agencies authorized. But for customers doing business with the company can catch up with the information about the change? Know that the responsibility belongs to the partner must learn before signing the contract with the company. The theory is that, but for the region with economic conditions particularly difficult social or undeveloped technology, the control that ensures whether or not. These are just a few of the issues in which there is a risk of abusive, profitable or otherwise violating conduct via the transaction nature of the interest by the manager of the company.

In fact, in Vietnam, the activities of the board of supervisors are lacking and weak. The 
establishment of a board of supervisors or controllers only in limited liability companies depends on the number of members in the company or on the need for corporate governance. A limited liability company with two or more members has the Members 'Council, the chairman of the Members' Council, the director or general director. Limited liability companies with 11 members or more must establish a board of supervisor; in case there are less than 11 members, the board of supervisor may be established in accordance with corporate governance requirements. The number of limited liability companies with Board of Supervisors was only below the average of $44.2 \%$ of the 226 surveyed companies. Whereas for joint stock companies, the number of companies with the Board of Supervisors is $69.3 \%$.

\section{The resolutions of the board members of the company}

Enterprise Law 2014 stipulates that the resolution of the Members' Council takes effect from the date of its adoption or the effective date stated in such resolution (Law on Enterprises 2014 in Vietnam). In the event of a dispute related to the resolution of the Members' Council on the transfer of capital contribution or increase or reduction of charter capital, which affects the ownership of the capital contribution, company members may initiate a lawsuit requesting the Court to revoke the adopted resolution. Together with the application of emergency measures temporarily suspend the implementation of part of the resolution. At this time, the resolution of the Members' Council, even if it is the lawsuit, is still effective as stipulated in Article 63 of the Law on Enterprises 2014.

\section{The cooperation between enterprises}

The exchange, cooperation between domestic enterprises and foreign investors in order to improve management capacity and to draw lessons learned on corporate governance of managers is limited. Therefore, the development of the company does not ensure the link with the development of the whole system of enterprises in the local as well as in the country. The number of company leaders fluent in foreign languages, knowledge of international law is not much. Few leaders are able to directly participate in negotiating, signing contracts, resolving disputes (especially international disputes). Therefore, it has a great influence on making judgments in the company's operations.

\section{Conclusions}

The activities of corporate governance of limited liability companies in Vietnam still face many shortcomings. These inadequacies and limitations are caused by various causes, internal causes and external factors. Whatever the cause, they have a direct or indirect impact on the performance of corporate governance and the company. Limited liability companies are owned by the owner and its members but in order to survive and develop, it is necessary to have a good governance system with the leadership of the Council members, the management of the board of directors and employee in the company. It can be said that corporate governance is a model of balance and control of power among the stakeholders to ensure the sustainable development of the company. With the principles, procedures and procedures in the issuance of decisions and orders of corporate governance and the executives will prevent the abuse of rights harm the company. So, towards building and promoting a transparent governance, effective in a limited liability company in Vietnam is an urgent requirement today. 


\section{Macrothink}

\section{References}

Civil Law of Vietnam. (2015).

Code of Civil Procedure of Vietnam. (2015).

Burkhard, W. M., Martin, H. H., \& Joachim, R. (2004). The German Limited Liability Company (6th ed.).

Karel, V. H., \& Harald, G. (2006). European Corporate Law. Nomos Verlagsgesellschaft (January 31, 2006).

Klaus, J. M. (2009). The GmbH - A guide to the German Limited Liability Company (2nd ed., p. 35), Verlag C. H. Beck München.

Law on Enterprises 2014 in Vietnam.

Martin, M. S., Samuel, W., Ivan Taback, Starting a limited liability company, John Wiley\&Sonc Inc, New Jersey, 2003, page 262.

Martin M. Shenkman, Samuel, W., \& Ivan, T. (2003). Starting a limited liability company (p. 262). John Wiley \& Sonc Inc, New Jersey.

Ngô, K. T. (2012). Giáo trình quản trị doanh nghiệp. Nhà xuất bản Đại học Kinh tế quốc dân,.

Patrick, C. L. (2005). German Company Law: Recent Developments and future challenges. German law journal, 6(10).

Tổng Cục thống kê (2017). Tình hình kinh tế - xã hội 6 tháng đầu năm 2017. Trang thông tin tình hình kinh tế-xã hội, tại địa chỉ http://www.gso.gov.vn/default.aspx?tabid=621\&ItemID=18471 ngày truy cập 03/7/2017

VCCI: Báo cáo thường niên doanh nghiệp Việt Nam 2016/2017.

\section{Copyright Disclaimer}

Copyright for this article is retained by the author(s), with first publication rights granted to the journal.

This is an open-access article distributed under the terms and conditions of the Creative Commons Attribution license (http://creativecommons.org/licenses/by/3.0/). 